\title{
Diagnostic polymerase chain reaction assay to detect Kudoa neurophila (Myxozoa: Multivalvulida) in a marine finfish hatchery
}

\author{
G. Grossel ${ }^{1, *}$, J. Handlinger ${ }^{2}$, S. Battaglene ${ }^{3}$, B. Munday ${ }^{1}$ \\ ${ }^{1}$ School of Human Life Sciences, University of Tasmania, Launceston, Tasmania 7250, Australia \\ ${ }^{2}$ Tasmanian Aquaculture \& Fisheries Institute, Fish Health Unit, Launceston, Tasmania 7250, Australia \\ ${ }^{3}$ Tasmanian Aquaculture \& Fisheries Institute, Marine Research Laboratories, Taroona, Tasmania 7053, Australia
}

\begin{abstract}
A single-round polymerase chain reaction (PCR) diagnostic assay was developed from a small subunit ribosomal DNA (SSU rDNA) gene sequence to detect the myxozoan parasite Kudoa neurophila, the causative agent of myxozoan disease in the hatchery reared marine finfish, striped trumpeter Latris lineata (Forster). The assay was developed for use as a disease control management tool in a hatchery system specifically designed to research and produce marine finfish such as striped trumpeter juveniles for aquaculture. The assay is sufficiently species specific and sensitive enough to detect a small fragment of the parasite's SSU rDNA. At the lower limits of detection, the test is consistently positive to an estimated 0.1 spore or $60 \mathrm{fg}$ of parasite DNA per $25 \mu \mathrm{l}$ PCR reaction in serial dilution and positive to an estimated 0.1 spore in $25 \mathrm{mg}$ of infected fish CNS tissue (4 spores $\mathrm{g}^{-1}$ ). Specifically, the test is capable of detecting early stages of the life cycle within the fish host and consequently diagnosing an infection not normally detected using traditional histological techniques. The test is also effective for screening water supplies and prey species cultures throughout the hatchery system to determine bio-security efficacy, to assist in identification of an alternate or other primary fish host, to indicate the location of potential disease reservoirs, and to enable a targeted approach to disease prevention.
\end{abstract}

KEY WORDS: Aquaculture $\cdot$ Myxozoa $\cdot$ Kudoa neurophila $\cdot$ PCR $\cdot$ Striped trumpeter

\section{INTRODUCTION}

Global marine finfish aquaculture has more than doubled since 1992 (FAO Yearbook 2001). Many countries are commercially producing a diverse range of species to meet the market and resource demands of the 21st century. In Tasmania, Australia, the State Government has initiated programs to capitalise on improved marine aquaculture technology and the pristine marine environment in order to foster a competitive and diverse marine aquaculture industry. The Tasmanian Aquaculture \& Fisheries Institute (TAFI) has identified marine finfish species with aquaculture potential. It is currently developing striped trumpeter Latris lineata (Forster) as a marine aquaculture species suitable for sea cage rearing (Battaglene et al. 2003) to supplement the existing Atlantic salmon industry.

Shortly after research on this species commenced, the myxozoan Kudoa neurophila (Grossel et al. 2003), a marine multivalvulid histozoic parasite with pentavalvid spores infecting the tissue of the central nervous system (CNS), was discovered during routine histological analysis. The disease caused by the parasite is a severe meningoencephalomyelitis, extensive throughout the brain and spinal cord and in all neural tissue types except peripheral nerves (Grossel et al. 2002). Although the mode of transmission of this parasite is unknown, it is generally accepted that the complex myxozoan life cycle involves myxozoan and actinosporean life stages within a fish and invertebrate host 
respectively (Wolf \& Markiw 1984). An invertebrate or alternative host for $K$. neurophila responsible for releasing the infective actinosporean stage of the parasite has not yet been discovered, although juvenile fish are believed to become infected during larval stages and develop nervous aberrations suggestive of a disease of the CNS around $70 \mathrm{~d}$ post hatch (dph). Mature spores of $K$. neurophila representing the terminal life cycle stage within the fish host can first be detected with a high prevalence of infection (100\% in surviving fish) from approximately $100 \mathrm{dph}$ (Grossel et al. 2002). This developmental pattern is similar to other closely related marine Myxozoa such as Kudoa thyrsites in netpen-reared Atlantic salmon (Moran et al. 1999). K. neurophila has been recognised as a significant disease restricting striped trumpeter culture assessment. The disease directly inhibits the production of sufficient quantities of viable juvenile fish required to test large-scale marine aquaculture.

Pentavalvid forms of Kudoa were previously morphologically distinguishable as species belonging to the genus Pentacapsula by having 5 shell valves and 5 polar capsules (Naidenova \& Zaika 1970, Lom \& Dykova 1992) with only 4 species discovered to date (Naidenova \& Zaika 1970, Cheung et al. 1983, Kovaleva \& Gaevskaya 1984, Grossel et al. 2003). However, comparative small subunit ribosomal DNA (SSU rDNA) gene sequence analysis shows Kudoa neurophila to be very closely related to other histozoic marine multvalvulids with 4 or more shell valves and polar capsules residing within the family Kudoidae. Recent molecular phylogeny studies propose that the Pentacapsula, Hexacapsula and Septemcapsula genera be synonymised in favour of Kudoa (Whipps et al. 2003, 2004). This is the first 5 polar capsule species of the Kudoa genus to be discovered in Australia and the first to cause significant disease problems in a species being examined for aquaculture.

At the present stage of research into Kudoa neurophila there are large gaps in our understanding of its biology, hence effective control has initially been based on environmental management, health management strategies and quarantine to prevent infection by the parasite. A very sensitive and specific DNA-based diagnostic test using standard polymerase chain reaction (PCR) molecular technology is a management tool capable of detecting early developmental stages of the parasite or very light but mature infections in the fish host. The ability of PCR to perform this function is particularly useful as it can detect sub-clinical myxozoan infections much earlier than routine histology (Saulnier \& de Kinkelin 1997, Andree et al. 1998, Kent et al. 1998, Palenzeula et al. 1999, Yokoyama et al. 2000, Morris et al. 2002). In the case of $K$. neurophila, traditional techniques such as light microscope examina- tion of stained sections and wet squash preparations are only effective in detecting the terminal spore forming stage and, in rare instances, presporogonic plasmodial stages of the disease. This study reports on the development of an efficient, sensitive and specific single-round PCR diagnostic assay for detecting a fragment of the SSU rDNA gene of $K$. neurophila and its use in the hatchery as an effective aquaculture health management tool.

\section{MATERIALS AND METHODS}

Animals and spore isolation. Striped trumpeter collected for this study displayed clinical signs of disease such as scoliosis and loss of spatial control. The fish were spawned and cultured at TAFI, Marine Research Laboratories, Taroona, Hobart, Tasmania, Australia (Battaglene et al. 2003). The infected fish from which mature spores were extracted ranged in age and size from $643 \mathrm{dph}, 88 \mathrm{~g}$ to $783 \mathrm{dph}, 273 \mathrm{~g}$. Brains and spinal cords were removed and neural tissue was digested by autolysis in $0.9 \%$ saline solution at $20^{\circ} \mathrm{C}$ for $4 \mathrm{~d}$. The liquefied tissue was then subjected to a sedimentation/floatation technique to extract mature intact spores by overlaying $1 \mathrm{ml}$ of liquefied tissue onto $10 \mathrm{ml}$ of $\mathrm{NaCl}$ solution with a specific gravity of 1.2 and centrifuged at $2100 \times g$ for $30 \mathrm{~min}$. The resulting spore pellet was washed by re-suspending it twice in phosphate buffered saline (PBS) $(\mathrm{pH} 7.4,1 \mathrm{M})$ prior to final collection.

DNA extraction and primers. DNA was extracted using the DNeasy Tissue Kit (QIAgen) according to the manufacturer's protocol. DNA was routinely extracted from $25 \mathrm{mg}$ of tissue and suspended in $100 \mu \mathrm{l}$ of the buffer provided in the kit unless otherwise stated. All DNA was quantified using an Eppendorf BioPhotometer (Brinkmann). SSU rDNA sequence (GenBank accession number AY172511) of 1552 base pairs from the 5' end and 18e primer (Hillis \& Dixon 1991) was subject to National Centre for Biotechnology Information (NCBI) BLAST searches (Altschul et al. 1997). The sequences from closely related species were then aligned using ClustalX (Thompson et al. 1997) and used to design primers from regions that displayed sufficient variation from the alignment of sequences. Twelve 20-24mer oligonucleotide primers were subsequently designed giving 20 possible primer combinations. The physical characteristics for each primer were tested for suitability using Net Primer (available at www.premierbiosoft.com). Each primer was subject to NCBI BLAST searches to determine the individuality of each primer sequence. Only primers specific to Kudoa neurophila that did not match any other known GenBank sequence were selected for testing. 
Specificity. To further determine specificity, the primers were tested against the target species, a panel of related myxozoan species and a panel of non-target environmental isolates. The target species consisted of template DNA extracted from Kudoa neurophila. The related species panel consisted of template DNA extracted from closely related species including: Kudoa sp. (Langdon 1990) from cysts of infected southern bluefin tuna Thunnus maccoyii muscle tissue collected from farmed fish in Port Lincoln, South Australia; Kudoa thyrsites from Atlantic mackerel Scomber scombrus muscle, France; Kudoa ovivora from the ovaries of bluehead wrasse Thalassoma bifasciatum, Panama; and Kudoa sp. (Hexacapsulid form) from the muscle of moon wrasse Thalassoma lunare, Great Barrier Reef, Australia. A local myxozoan, Myxobolus aldrichetti from the gill of mullet Aldrichetti forsteri was also included in the panel. The non-target environmental isolate panel consisted of template DNA from wild caught adult striped trumpeter Latris lineata (primary host); rainbow trout Oncorhynchus mykiss; greenback flounder Rhombosolea tapirina; damsel fish Acanthochromis polyacanthus and blue throat wrasse Notolabrus tetricus (primary host). All fish except for wild striped trumpeter and wild blue throat wrasse were spawned and cultured at the School of Aquaculture, University of Tasmania, Launceston, Tasmania, Australia. Template DNA from the polychaete worm Galeolaria caespitose was included as a potential alternative host representative.

Sensitivity. Sensitivity of the PCR was initially determined in the laboratory using a serial dilution of Kudoa neurophila DNA to find the lowest limit of detection of the target organism. Spores were counted using a haemocytometer prior to DNA extraction. DNA was extracted from 1000 spores and resuspended in $100 \mu \mathrm{l}$ of buffer provided (10 spores $\left.\mathrm{\mu l}^{-1}\right)$ followed by 10 -fold dilutions in sterile distilled water ( 1 and 0.1 spore $\mu l^{-1}$ respectively). Serial dilutions were used to determine the lowest number of spores able to be detected by producing a response from a single-round $25 \mu \mathrm{l}$ PCR that could be easily visualised on a gel. Sensitivity dilutions were also seeded with striped trumpeter DNA extracted from $25 \mathrm{mg}$ of uninfected brain tissue to simulate infected fish and determine any inhibitory effect of the fish DNA in the PCR reaction. To further test the sensitivity of PCR for use in the hatchery, 3 samples of uninfected striped trumpeter brain weighing $25 \mathrm{mg}$ were seeded with 1000, 100 and 10 spores respectively prior to DNA extraction. DNA was resuspended in the standard $100 \mu \mathrm{l}$ of buffer provided to produce 10, 1 and 0.1 spore $\mu^{-1}$ respectively for use in the PCR reaction. Positive controls for PCR reactions included template DNA from infected striped trumpeter brain and spinal cord samples. These fish were histologically deter- mined to be heavily infected with the parasite in the terminal stage of infection by Hematoxylin \& Eosin (H\&E) stained brain sections and wet squash preparations using a light microscope. Negative controls in PCR reactions included template DNA from the brain tissue of wild caught adult striped trumpeter, determined to be uninfected by histology.

PCR reaction and thermocycling. All PCR reactions were carried out in $25 \mu \mathrm{l}$ volumes consisting of $18.6 \mu \mathrm{l}$ sterile distilled $\mathrm{H}_{2} \mathrm{O}, 1 \times$ PCR buffer, $3.5 \mathrm{mM} \mathrm{MgCl}$, $0.2 \mathrm{mM}$ dNTP, $12.5 \mathrm{pmol}$ of each primer, 1 unit Platinum ${ }^{\circledR}$ Taq DNA Polymerase (Invitrogen) and $1 \mu \mathrm{l}$ of template DNA. Amplifications were performed using an MJ Research PTC-200 Peltier Thermal Cycler (MJ Research). DNA was denatured for $3 \mathrm{~min}$ at $95^{\circ} \mathrm{C}$. Twenty-nine amplification cycles were performed as follows: $30 \mathrm{~s}$ at $94^{\circ} \mathrm{C}$ for denaturation, $45 \mathrm{~s}$ for primer annealing at $63.2^{\circ} \mathrm{C}$, and $1 \mathrm{~min}$ for $\mathrm{Taq}$ extension at $72^{\circ} \mathrm{C}$. Four $\mu \mathrm{l}$ of the PCR product were electrophoresed on a $1 \%$ agarose gel then stained in a water bath containing $0.4 \mathrm{\mu g} \mathrm{ml}^{-1}$ ethidium bromide stock solution in distilled water for $30 \mathrm{~min}$ and visualised over a UV transilluminator box. PCR products were purified using a QIAquick PCR purification kit (QIAgen) following the manufacturer's protocol. Sequencing was carried out by Supamac Laboratories, Sydney, Australia, on an ABI 3700 automated sequencer for positive identification by comparison with the Kudoa neurophila SSU rDNA gene sequence.

PCR efficiency. The efficiency of the PCR could not be tested against striped trumpeter owing to $100 \%$ infection rates which were easily detected using all diagnostic methods. A local wild fish species, blue throat wrasse Notolabrus tetricus, inhabits the area surrounding the hatchery water intake. This species was found to be infected by Kudoa neurophila at a low prevalence compared to cultured striped trumpeter juveniles. Due to the low prevalence of infection and comparatively low susceptibility to the disease, the blue throat wrasse was chosen as an appropriate model for testing PCR efficiency compared to traditional histological techniques. Fourteen sample fish were caught by trap and handline from around the seawater intake. Brains and spinal cords were collected. One $25 \mathrm{mg}$ brain sample was placed in $95 \%$ ethanol for PCR, one sample placed in $10 \%$ neutral buffered formalin (NBF) for histological examination (H\&E stained $5 \mu \mathrm{m}$ section) and a final wet preparation sample was squashed with a drop of filtered, sterilised saline solution and viewed under a light microscope. A positive or negative result was recorded for wet preparation and H\&E stained sections by the presence or absence of the mature spore stage in CNS tissue. DNA taken from a fin clipping of a disease free blue throat wrasse was used as a nega- 
tive control for PCR. Positive PCR samples were sequenced and compared to the $K$. neurophila SSU rDNA gene sequence.

Detection of earlier life stages. To detect early life stages of the parasite within the fish host, PCR was used on a cohort of winter spawned cultured juvenile fish. Unsampled fish from this group subsequently developed $100 \%$ infection, displaying mature spores in wet squash preparations and in the terminal stage of the parasite life cycle at $136 \mathrm{dph}$. Sample fish were stored in $95 \%$ ethanol refreshed weekly prior to use. Template DNA was extracted from the fish at 23, 44, 77 and $136 \mathrm{dph}$ ( $\mathrm{n}=20$ at each time point). Remains of whole fish from 23 and $44 \mathrm{dph}$ following wet-squash preparation and sampling for $\mathrm{H} \& \mathrm{E}$ were used to extract DNA and $\leq 25 \mathrm{mg}$ brain samples were used for the fish at 77 and $136 \mathrm{dph}$. DNA was resuspended in $100 \mu \mathrm{l}$ and stored at $-20^{\circ} \mathrm{C}$ prior to use.

PCR tests on hatchery materials. Following development, the PCR test was used to determine the presence and infection potential of the parasite within and around the hatchery. This information was used to facilitate health management decisions and ongoing epizootiological studies.

Incoming untreated seawater, thought to be the source of the infectious actinosporean stage of the disease, was filtered to $1 \mu \mathrm{m}$ using a microfibre filter bag (Filter Specialists). DNA was extracted from $25 \mathrm{mg}$ filtrate samples and subjected to PCR. Incoming seawater treated with sand and cartridge filters, foam fractionation, ozonation, UV sterilisation and charcoal filtration was also filtered to $1 \mu \mathrm{m}$ and DNA was extracted using the same technique described above. Samples were collected and analysed by PCR every week throughout the spawning season extending from June to December 2003 ( $\mathrm{n}=56$ ). Rotifer and artemia cultures prepared with treated seawater and used as prey species for juvenile fish, were routinely sampled and tested using PCR once every week. Ten species of wild fish thought to possibly act as other fish hosts for the parasite were opportunistically collected using trap and handline from around the seawater intake. Brain samples (25 mg) were collected and subjected to PCR. Invertebrates such as oligochaete and polychaete worms, thought to represent potential alternative hosts for the parasite life cycle and responsible for releasing the infectious actinosporean stage, were collected throughout 2003 from the hatchery system, the neighbouring aquatic reserve and from immediately around the seawater intake. Two types of oligochaete and 4 types of polychaete worms were sampled. Only 1 polychaete, Galeolaria caespitose, was identified to species level. Approximately 1500 worms were sampled from each worm type. Following wet squash examination, invertebrates suspected to be infected were subject to
PCR testing. To determine the infection status of adult striped trumpeter used for broodstock a total of 56 wild adult striped trumpeter and 23 specially selected broodstock fish collected from various locations around the waters of Tasmania were subject to PCR testing and CNS tissue wet squash preparations.

\section{RESULTS}

All 20 primer combinations from the 12 primers designed and tested for this assay produced PCR fragments of the predicted size that were $100 \%$ identical to Kudoa neurophila SSU rDNA gene sequence. There were no non-specific products visualised on $1 \%$ agarose gel. Subsequent validation of each primer pair resulted in the elimination of unsuitable combinations. These combinations failed specificity testing by amplifying PCR products from closely and further phylogenetically removed myxozoan template DNA which, when visualised, appeared identical in size to the $K$. neurophila target fragment. Some combinations produced many non-specific amplicons when tested against the template DNA of the closely related species panel and non-target environmental isolates panel. The non-specific amplification could not be satisfactorily removed through optimising thermocycling or PCR reaction conditions. The PEN3F-PEN4R primer pair (sense primer PEN3F 5'-GA CCC ATC AAA GAC TCA CTA-3' and antisense primer PEN4R 5'-CC AAA GCC GAA ACA CTA GGT-3') proved to be the most successful and displayed a specific single DNA fragment, consistently able to produce a 188 base pair single-round PCR product fragment 100\% identical to $K$. neurophila sequence from infected host CNS tissue.

\section{Specificity}

The PEN3F-PEN4R primer combination, when further tested against template DNA from closely related and a local myxozoan species showed positive single DNA fragment specificity to Kudoa neurophila under the optimised PCR reaction and thermocycling conditions. No positive results or non-specific products were visualised for any of the closely related myxozoan species tested. Specificity of the PEN3F-PEN4R primer combination was further validated when tested against the non-target environmental isolates panel by displaying no amplification against any of the fish or polychaete worm template DNA (Fig. 1). This result suggests no interference to the PCR reaction by host or other DNAs tested when using a standard $25 \mathrm{mg}$ sample. 


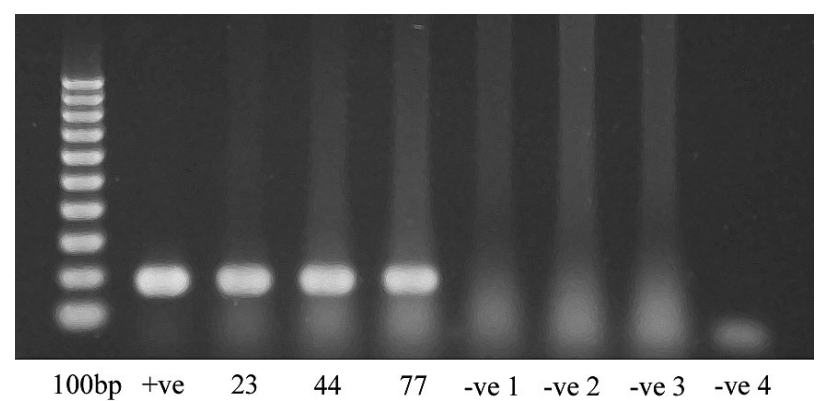

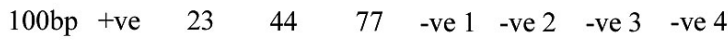

Fig. 1. Detection of early stages of parasite infection in juvenile cultured striped trumpeter with positive (+ve) and negative (-ve) controls. The positive control contains DNA from heavily infected fish brains at $136 \mathrm{dph}$. Lanes 23, 44 and 77 refer to the age of the fish in days post hatch. All juvenile fish were from the same cohort. -ve 1 contains uninfected wild striped trumpeter DNA. -ve 2 contains uninfected blue throat wrasse DNA. -ve 3 contains polychaete worm Galeolaria caespitose DNA. -ve 4 contains no DNA in the PCR reaction

\section{Sensitivity}

The limit of sensitivity of the single-round PCR assay from serially diluted preparations, also containing host template DNA and from spiked $25 \mathrm{mg}$ CNS tissue samples prior to DNA extraction, was consistently achieved at an estimated 0.1 spore per $25 \mu$ reaction (Fig. 2). Quantification of Kudoa neurophila DNA extracted from known spore numbers and dilutions was shown to be as low as $60 \mathrm{fg}$ per positive PCR reaction. Positive PCR signals for DNA equivalent to 0.1 spore using a standard $25 \mathrm{mg}$ of CNS tissue in each DNA extraction extrapolates to a sensitivity measure approximately equivalent to 4 spores $\mathrm{g}^{-1}$. Although consistency was also achieved at an estimated 0.01 spore per PCR reaction, PCR product intensity visualised under UV illumination varied from very faint to barely detectable following the standard 30 min ethidium bromide staining procedure. Specific positive DNA fragments were $100 \%$ identical to K. neurophila following sequencing and no other PCR products or false negative results were observed from the inclusion of uninfected host CNS tissue prior to DNA extraction.

\section{PCR efficiency}

Of the 14 blue throat wrasse collected from around the seawater intake, 3 (21\%) were shown to harbour mature Kudoa neurophila spores in CNS tissue using wet squash preparations. The same 3 fish (21\%) were diagnosed as infected following sectioning and H\&E staining. The PCR test also showed a positive result for the same 3 fish and a positive result for 2 additional fish (36\%) previously shown to be disease free by the 2 other diagnostic methods employed (Table 1). Overall, the PCR test detected a further $15 \%$ of infections from the population sampled and proved $66 \%$ more efficient than traditional diagnostic techniques when used on the blue throat wrasse model. PCR products following sequencing were $100 \%$ identical to the $K$. neurophila SSU rDNA gene sequence. DNA from disease free blue throat wrasse did not result in false positive signals (Fig. 1).

\section{Detection of early life stages}

PCR analysis was tested on a 2002 winter spawning cohort of larval and juvenile striped trumpeter $(23,44$, 77 and $136 \mathrm{dph}$ ) exposed to untreated seawater. The terminal stage of infection with mature parasite spores in the CNS was confirmed in all $136 \mathrm{dph}$ fish by microscopic examination of H\&E stained $5 \mu \mathrm{m}$ sections and wet squash preparations. The few surviving fish were noted to be very heavily infected with the parasite and some fish showed displacement of up to $80 \%$ of brain and spinal cord tissue by parasite pseudocysts. All preserved fish with infections of earlier parasite presporogonic life stages undetected in H\&E stained $5 \mu \mathrm{m}$ sections, wet squash preparations or diff-quick stained brain smears were positive to the Kudoa neurophila SSU rDNA 188 base pair fragment when tested against negative and positive controls (Table 1, Fig. 1).

\section{PCR tests on hatchery materials}

Untreated seawater filtrates drawn from the adjacent aquatic reserve were consistently positive using the PCR test whereas seawater filtrates following purification treatments were negative (Table 2). Prey species cultures of rotifer and artemia sampled throughout the

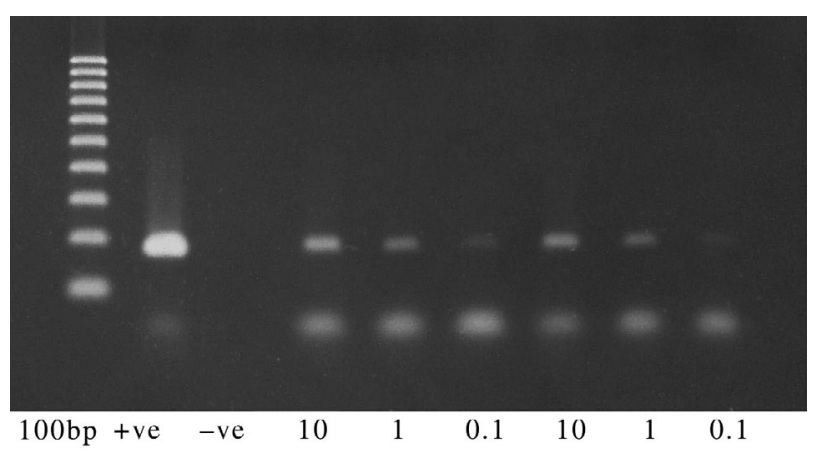

Fig. 2. Sensitivity with positive (+ve) and negative (-ve) controls. Ten-fold serial dilution containing striped trumpeter DNA equivalent to 10 spores to 0.1 spore followed by $25 \mathrm{mg}$ striped trumpeter CNS tissue spiked with mature spores prior to DNA extraction to give 10, 1 and 0.1 spore per $25 \mu \mathrm{l}$ PCR reaction 
Table 1. Polymerase chain reaction (PCR) efficiency when tested on the blue throat wrasse model and striped trumpeter early life stages. Fourteen adult blue throat wrasse and 20 striped trumpeter from each life stage at 23,44,77 and 136 dph were tested for parasites using wet squash preparations (Wet), H\&E stained $5 \mu \mathrm{m}$ sections (H\&E) and PCR. Positive and negative infections are shown as + and - respectively and the percentage of positive infections are calculated at the bottom of each column for the blue throat wrasse model

\begin{tabular}{|cccc|}
\hline Fish \# & Wet & H\&E & PCR \\
\hline 1 & + & + & + \\
2 & - & - & - \\
3 & - & - & - \\
4 & - & - & - \\
5 & - & - & + \\
6 & + & + & + \\
7 & - & - & - \\
8 & - & - & + \\
9 & + & + & - \\
10 & - & - & - \\
11 & - & - & - \\
12 & - & - & + \\
13 & - & - & $36 \%$ \\
14 & - & - & + \\
$\%$ & $21 \%$ & $21 \%$ & + \\
\hline 23 dph & - & - & + \\
44 dph & - & - & + \\
77 dph & - & + & \\
136 dph & + & & \\
\hline
\end{tabular}

spawning season were negative by the PCR test (Table 2). Of the 52 wild fish from 10 species sampled around the seawater intake, 12 fish from 7 species representing 45 fish (27\% from infected species) were positive for Kudoa neurophila (Table 2). Wild infected species were as follows: 6 spined leather jacket Meuschenia freycineti $(\mathrm{n}=5)$, blue throated wrasse Notolabrus tetricus $(\mathrm{n}=14)$, jackass morwong Nemadactylus macropterus ( $\mathrm{n}=4$ ), brown striped leather jacket Meuschenia australis $(\mathrm{n}=2)$, purple wrasse Notolabrus fucicola ( $\mathrm{n}=3$ ), ruddy gurnard perch Neosebastes scorpaenoides $(\mathrm{n}=1)$ and sand flathead Platycephalus bassensis $(\mathrm{n}=16)$. No invertebrates were observed to be infected with a myxozoan life cycle stage by wet squash preparation and all suspected infections subject to PCR were found to be negative (Table 2). Wild collected adult striped trumpeter were negative by PCR and of the 23 broodstock fish tested, 1 fish was found to have a very mild infection with a single cyst visualised in wet squash and positive in PCR (Table 2). This adult male fish was collected from the wild and had been held in captivity for 18 mo over the 2002 and 2003 spawning seasons. The fish displayed unusual behaviour, fast uncontrolled swimming and suffered acute stress necessitating euthanasia.
Table 2. Number of PCR positive (\# +VE PCR) or negative (\#-VE PCR) results from tests conducted in the hatchery and from the adjacent aquatic reserve and seawater intake. Preand post-treated water filtrates and prey species were sampled once per wk for 28 wk over the spawning period from June to December 2003

\begin{tabular}{|lrc|}
\hline PCR Subject & \# +VE PCR & \# -VE PCR \\
\hline Pre-treated water filtrates & 28 & 0 \\
Post-treated water filtrates & 0 & 28 \\
Wild fish species & 12 & 45 \\
Rotifer (early stage prey) & 0 & 28 \\
Artemia (later stage prey) & 0 & 28 \\
Suspected invertebrates & 0 & 15 \\
Wild striped trumpeter & 0 & 56 \\
Adult broodstock fish & 1 & 22 \\
\hline \multicolumn{2}{c}{ DISCUSSION } \\
\hline
\end{tabular}

Traditionally, diagnosis of Kudoa neurophila in striped trumpeter depended on microscope examination of H\&E stained sections through the CNS, wet squash preparations and Giemsa or diff-quick stained smears from brain or spinal cord tissue. All 3 traditional histological techniques rely upon the ability to visualise the distinctive pentagonal features of the parasite in its terminal mature spore stage within the definitive fish host. These traditional diagnostic tools are unable to detect early or presporogonic stages of the parasite, the migratory route it takes through the fish to the CNS or its morphological characteristics as the parasite develops to terminal stage sporulation. Diagnosis of the parasite at the mature spore stage is too late for the hatchery manager to take preventative measures against infection, because by this stage, any surviving fish are $100 \%$ infected and will not survive or be of the quality required for research or an intensive aquaculture situation such as sea cage rearing. Traditional methods are also labour intensive, cost inefficient and limited in their overall use as an effective diagnostic and health management tool. The highly specific and sensitive molecular test we have developed utilises PCR to detect SSU rDNA from any parasite developmental stage, particularly in the early stage. It provides a flexible, multiple use tool with diagnostic and health management capabilities which is more cost effective and quicker than traditional methods. The test is also designed to utilise commercially available molecular, easy to operate biology kits that have been shown here to be effective, efficient and reliable when used in the field situation. Myxozoan detection research has determined similar outcomes using the PCR approach to diagnosis and health management for both wild fishery management and aquaculture worldwide (Saulnier \& de Kinkelin 1997, Andree et al. 1998, Kent et al. 
1998, Palenzuela et al. 1999, Morris et al. 2002, Yokoyama et al. 2000).

The single-round PCR test was able to specifically amplify a fragment of the SSU rDNA from Kudoa neurophila and strong amplicons were always visualised from fish known to harbour the parasite infection at the terminal stage as determined by traditional histology. The short 188 base pair fragment from the PEN3FPEN4R primer combination performed with better amplification efficiency to target the SSU rDNA than any other primer combination tested. A similar result was reported by Docker et al. (1997), demonstrating greater efficiency for shorter PCR fragments to detect the microsporean Loma salmonae parasitising chinook salmon Oncorhynchus tshawytscha.

Following establishment of an acceptable level of specificity to Kudoa neurophila SSU rDNA, further testing confirmed the lower limits of detection with the robust PEN3F-PEN4R primer combination. This was shown to be consistent with an estimated 0.1 spore per $25 \mu \mathrm{l}$ PCR reaction (60 fg DNA, 4 spores $^{-1}$ tissue) both in laboratory controlled serial dilutions of spore template DNA and in brain tissues that had been spiked with spores prior to DNA extraction. Although very faint, yet consistent products were attained at an estimated 0.01 spore, human error caused by the inability to visualise such a weak signal is likely to result in a false negative outcome. Sensitivity for this diagnostic assay is similar to previous myxozoan single-round PCR based tests developed to date (Kent et al. 1998, Palenzuela et al. 1999, Morris et al. 2002) and is more sensitive than current diagnostic methods. Accuracy in diagnosis is also improved by the ability to process whole fish, whole brains and spinal cords, whereas techniques such as microscopic examination of $5 \mu \mathrm{m}$ sections only examines a portion of the targeted tissue introducing greater probability of error. Sensitivity was not compromised by the addition of host DNA or by seeding uninfected host tissue with known concentrations of spores prior to the DNA extraction process. This signifies that the presence of host DNA does not interfere with the PCR process and hence does not produce non-specific amplification or false positive results in controlled seeded matrix combinations of parasite and host DNA (Fig. 2).

By using the blue throat wrasse as a useful test model we were able to demonstrate the PCR method to be $66 \%$ more efficient when compared to routine traditional histological techniques. Future diagnostics for health management purposes will have increased accuracy and no longer need to rely entirely on traditional histological confirmation.

Twenty-three, 44 and $77 \mathrm{dph}$ fish that displayed no sign of infection when microscopically examined using H\&E stained sections, diff-quick stained spinal cord smears or wet squash preparations were found to be infected using the PCR test. The ability of this test to detect previously undetectable presporogonic life stages or possible light infections of the mature spore stage of the disease in an efficient and cost effective manner is of invaluable benefit and provides the aquaculture hatchery manager with a powerful diagnostic and decision making tool. Disease prevalence data collected will be used in an ongoing epizootiological study to determine periods of highest infection risk. A controlled spawning strategy such as phase shifting spawning events to times outside a window of highest infection risk may prove to be a contributing and effective health management strategy against this disease.

As part of the ongoing health management process the PCR test has been used to screen wild adult fish and mortalities among wild brood stock fish caught and conditioned in the same water believed to be the possible source of the actinosporean or infectious stage of the disease. So far, with the exception of a single broodstock fish, adult wild fish and brood stock fish exposed to untreated seawater and possible infectious stages have been found to be free of the parasite when examined microscopically and with the PCR diagnostic assay. It is unknown if the brood fish contracted the infection in the hatchery during its 18 mo stay or in the wild. If the parasite was contracted within the hatchery, susceptibility to disease was very low in comparison to heavily infected juvenile fish held under the same conditions during this time. This may suggest that striped trumpeter are only susceptible to heavy infection in the larval or juvenile stages or can be infected at low levels of intensity as adults. Alternatively, juvenile fish with very low levels of infection survive in the wild to adulthood as seen in the local wild fish species. The PCR result indicating very low prevalence of the infection in adult wild striped trumpeter used for broodstock does not point to these fish as being the source of the disease. The developmental point at which hatchery fish are no longer susceptible will require determination through attempted transmission of infection to naïve age classes so that a strategic reduction in the costly anti-parasitic health management measures can occur and fish can be conditioned to natural seawater prior to sea cage rearing.

To gain a more complete biological and epizootiological understanding of the parasite and the disease it causes, the PCR was field tested within and outside the hatchery system. The results confirm another 7 species of fish resident within the aquatic reserve and inhabiting the area around the seawater intake for the hatchery were infected with Kudoa neurophila, albeit at lower prevalence and infection intensity than cultured juvenile striped trumpeter. Further positive PCR results from the incoming water filtrates and negative 
PCR results from within the hatchery suggest that the parasite occurs naturally in some species of wild fish within the reserve, and the infectious actinosporean stage of the parasite released from an alternative worm host is being drawn into the hatchery system from this area. In effect, the aquatic reserve and some species of fish and invertebrates resident therein act as the reservoir for the parasite and the hatchery is providing the conditions necessary for the disease to flourish amongst the juvenile cultured fish. As a result, the health management decision to treat water before entering the hatchery system was implemented and the PCR is applied to pre- and post-water treatment filtrate samples to gauge the efficacy and bio-security of the water treatment system. However, it is possible that use of PCR may detect DNA from presumptive actinosporean stages in the incoming water as well as non-living life stages of $K$. neurophila in the stomach contents of prey species or pre-actinosporean parasite stages in infected alternative hosts. Application of the tool in this form also raises the question of false positives, which are likely due to limitation of PCR specificity against every possible environmental isolate entering the hatchery (Hiney \& Smith 1998). Positive results from filtrates would require sequencing to further validate the result and this approach may be time consuming and cost prohibitive. However, testing water filtrates pre- and post-treatment provides an effective broad screening technique. The negative PCR results in post-treatment filtrates indicates that the water treatment system eliminates the possibility of a potential infectious actinosporean stage of the parasite entering the hatchery during the spawning and larval rearing period when it is believed that the fish are most at risk of infection. Negative results from post-treatment filtrate samples have provided the information required for implementing effective disease management. They have also shown that the infectious stage may be present in the incoming water throughout the entire current spawning season, warranting continued surveillance and maintenance of the water treatment system.

To further understand the biology of this parasite the PCR assay will continue to be used to extensively screen invertebrate populations in and around the hatchery and water intake to test for the presence of an infected alternative host. PCR results have previously been successfully used to link myxozoan life stages on a molecular level to initially determine possible alternative host candidates and also used to add evidential weight to transmission and life cycle studies (Andree et al. 1997, Bartholomew et al. 1997, Anderson et al. 1999, 2000, Lin et al. 1999, Pote et al. 2000, Negredo et al. 2003). By elucidating the life cycle of Kudoa neurophila through incorporating SSU rDNA sequence com- parison we hope to increase knowledge on the biology of marine myxozoans as only a single marine life cycle has been discovered so far (Køie et al. 2004).

Presporogonic morphological development of this histozoic parasite once it enters the fish and up to the terminal mature spore stage encapsulated within plasmodia in the CNS is still not clear. As part of pathology studies on this disease, the oligonucleotide primers developed for this assay are currently being incorporated into an in situ hybridisation technique to determine the route of entry and migratory development in the definitive fish host.

Myxozoan parasites of fish have the potential to cause problems among wild fish stocks and aquaculture. To date, molecular detection as a routine diagnostic tool has proved to be the most efficient and effective means available (Kent et al. 2001). Not only can this molecular technique be used for efficient and effective diagnosis, it has wider application extending beyond basic diagnostics as a flexible multiple use tool. It also has the added ability to perform biological and epizootiological research and ultimately facilitate correct implementation of health management decisions for the hatchery manager and researcher in an aquaculture situation.

Acknowledgements. This work was supported by TAFI. We would like to thank: Drs. M. Bransdon, J. Cobcroft and D. Moorehead, and Mr. R. Goldsmid of the TAFI striped trumpeter research team for providing material and information; Professor J. Ellis and Mrs. C. Ryce of the University of Technology, Sydney; Dr. C. Whipps and Professor M. Kent of Oregon State University for providing myxozoan DNA samples; Professor M. Ball, Associate Professor D. Geraghty, H. Binns and M. Johnson from the School of Human Life Sciences, University of Tasmania for providing facilities and laboratory support; Q. P. Fitzgibbon of the School of Aquaculture, University of Tasmania for providing live fish samples.

\section{LITERATURE CITED}

Altschul SF, Madden TL, Schäffer AA, Zhang J, Zhang Z, Miller W, Lipman DJ (1997) Gapped BLAST and PSIBLAST: a new generation of protein database search programs. Nucleic Acids Res 25:3389-3402

Anderson CL, Canning EU, Okomura B (1999) 18S rDNA sequences indicate that PKX organism parasitizes Bryozoa. Bull Eur Assoc Fish Path 19:94-97

Anderson CL, Canning EU, Schafer SM, Yokoyama H, Okomura B (2000) Molecular confirmation of the life cycle of Thelohanellus hovorkai Archmerov, 1960 (Myxozoa: Myxosporea). Bull Eur Assoc Fish Path 20:111-115

Andree KB, Gresoviac SJ, Hedrick RP (1997) Small sub unit ribosomal RNA sequences unite alternate actinosporean and myxosporean stages of Myxobolus cerebralis the causative agent of whirling disease in salmonid fish. J Eukaryot Microbiol 44:208-215

Andree KB, MacConnell E, Hedrick RP (1998) A nested polymerase chain reaction for the detection of genomic DNA of Myxobolus cerebralis in rainbow trout Oncorhynchus 
mykiss. Dis Aquat Org 34:145-154

Bartholomew JL, Whipple MJ, Stevens DG, Fryer JL (1997) The life cycle of Ceratomyxa shasta, a myxosporean parasite of salmonids, requires a freshwater polychaete as an alternative host. J Parasitol 85:859-868

Battaglene S, Brown M, Pankhurst T (2003) The development of marine fin-fish farming in Tasmania. In: Allen G (ed) NSW fisheries research report series 8:45-51. Proc Aquafin CRC Snapper Workshop. NSW Fisheries, Sydney

Cheung PJ, Nigrelli RF, Ruggieri GD (1983) Pentacapsula muscularis (Myxosporea: Pentacapsulidea); a histozoic parasite of butterflyfish, Chaetodon collare Bloch. J Fish Dis 6:393-395

Docker MF, Devlin RH, Richard J, Khattra J, Kent ML (1997) Sensitive and specific polymerase chain reaction assay for detection of Loma salmonae (Microsporea). Dis Aquat Org 29:41-48

FAO Yearbook (2001) FAO Yearbook of fishery statistics, Aquaculture production 92/2. CABI Publishing, Oxfordshire

Grossel GW, Ellis JT, Handlinger J, Dykova I, Munday BL (2002) Meningoencephalomyelitis causing mortality in striped trumpeter Latris lineata due to infection with a Pentacapsula sp. (Myxosporea). In: Impacts of myxozoan parasites in wild and farmed finfish, Nanaimo, BC, p 20

Grossel GW, Dykova I, Handlinger J, Munday BL (2003) Pentacapsula neurophila sp. n. (Multivalvulida) from the central nervous system of striped trumpeter, Latris lineata (Forster, 1801). J Fish Dis 26:315-320

Hillis DM, Dixon MT (1991) Ribosomal DNA: molecular evolution and phylogenetic inference. Q Rev Biol 66:411-453

Hiney MP, Smith PR (1998) Validation of polymerase chain reaction-based techniques for proxy detection of bacterial fish pathogens: framework, problems and possible solutions for environmental applications. Aquaculture 162: 41-68

Kent ML, Khattra J, Hervio DML, Devlin RH (1998) Ribosomal DNA sequence analysis of isolates of the PKX myxosporean and their relationship to members of the genus Sphaerospora. J Aquat Anim Health 10:12-21

Kent ML, Andree KB, Bartholomew JL, El-Matbouli M and 12 others (2001) Recent advances in our knowledge of the Myxozoa. J Eukaryot Microbiol 48:95-413

Køie M, Whipps CM, Kent ML (2004) Ellipsomyxa gobii (Myxozoa: Ceratomyxidae) in the common goby Pomatoschistus microps (Teleostei: Gobiidae) uses Neris spp. (Annelida: Polychaeta) as invertebrate hosts. Folia Parasitol 51:14-18

Kovaleva AA, Gaevskaya AV (1984) New species of the genera Kudoa and Pentacapsula (Myxosporidia: Multivalvulea) with unusual location. Zool Zh 63:1090-1092 (in Russian)

Langdon JS (1990) Observations of new Myxobolus species and Kudoa species infecting the nervous system of Australian fishes. J Appl Ichthyol 6:107-116

Lin D, Hanson LA, Pote LM (1999) Small subunit ribosomal

Editorial responsibility: Carey Cunningham,

Aberdeen, UK
RNA sequence of Henneguya exilis (Class Myxosporea) identifies the actinosporean stage from an oligochaete host. J Eukaryot Microbiol 46:66-68

Lom J, Dykova I (1992) Protozoan parasites of fishes. Developments in aquaculture and fisheries science, Vol 26. Elsevier Science Publishers, Amsterdam

Moran JDW, Margolis L, Webster JM, Kent ML (1999) Development of Kudoa thyrsites (Myxozoa; Myxosporea) in netpen-reared Atlantic salmon determined by light microscopy and polymerase chain reaction test. Dis Aquat Org 37:185-193

Morris DC, Morris DJ, Adams A (2002) Development of improved PCR to prevent false positives and false negatives in the detection of Tetracapsula bryosalmonae, the causative agent of proliferative kidney disease. J Fish Dis 25:483-490

Naidenova NN, Zaika VE (1970) Three new genera of Myxosporida - fish parasites from the Indian Ocean. Zool Zh 49:451-454 (in Russian)

Negredo C, Dillane MF, Mulcahy MF (2003) Small subunit ribosomal DNA characterization of an unidentified aurantiactinomyxon form and its oligochaete host Tubifex ignotus. Dis Aquat Org 54:229-241

Palenzeula O, Trobridge G, Bartholomew JL (1999) Development of a polymerase chain reaction diagnostic assay for Ceratomyxa shasta, a myxosporean parasite of salmonid fish. Dis Aquat Org 36:45-51

Pote LM, Hanson LA, Shivaji R (2000) Small subunit ribosomal RNA sequences link the cause of proliferative gill disease in channel catfish to Henneguya n. sp. (Myxozoa; Myxosporea). J Aquat Anim Health 12:230-240

Saulnier D, de Kinkelin P (1997) Polymerase chain reaction primers for investigations on the causative agent of proliferative kidney disease of salmonids. J Fish Dis 20:467-470

Thompson JD, Gibson TJ, Plewniak F, Jeanmougin F, Higgins DG (1997) The ClustalX windows interface: flexible strategies for multiple sequence alignment aided by quality analysis tools. Nucleic Acids Res 25:4876-4882

Whipps CM, Adlard RD, Bryant MS, Kent ML (2003) Two unusual myxozoans, Kudoa quadricornis n. sp. (Multivalvulida) from the muscle of gold spotted trevally (Carangoides fulvoguttatus) and Kudoa permulticapsula n. sp. (Multivalvulida) from the muscle of Spanish mackerel (Scomberomorus commerson) from the Great Barrier Reef, Australia. J Parasitol 89:168-173

Whipps CM, Grossel GW, Adlard RD, Yokoyama H, Bryant MS, Munday B, Kent ML (2004) The phylogeny of the Multivalvulidae (Myxozoa: Myxosporea) based upon comparative rDNA sequence analysis. J Parasitol 90:618-622

Wolf K, Markiw ME (1984) Biology contravenes taxonomy in the Myxozoa: new discoveries show alternation of invertebrate and vertebrate hosts. Science 225:1449-1452

Yokoyama H, Inoue D, Sugiyama A, Wakabayashi H (2000) Polymerase chain reaction and fluorescent antibody technique for the detection of Kudoa amamiensis (Multivalvulida: Myxozoa) in yellowtail Seriola quinqueradiata. Fish Pathol 35:157-162

Submitted: July 14, 2004; Accepted: November 19, 2004

Proofs received from author(s): March 9, 2005 